$$
\text { UAH }
$$

\title{
Pintura
}

\section{Paseo entre Lirios}

\section{Carmen González Hernández}

Profesora Asociada en Ciencias de la Salud, Facultad de Medicina y Ciencias de la Salud, Universidad Alcalá; carmengonzalezhernandez58@gmail.com

“Paseo entre Lirios", 2018 (45 X 55 cm)

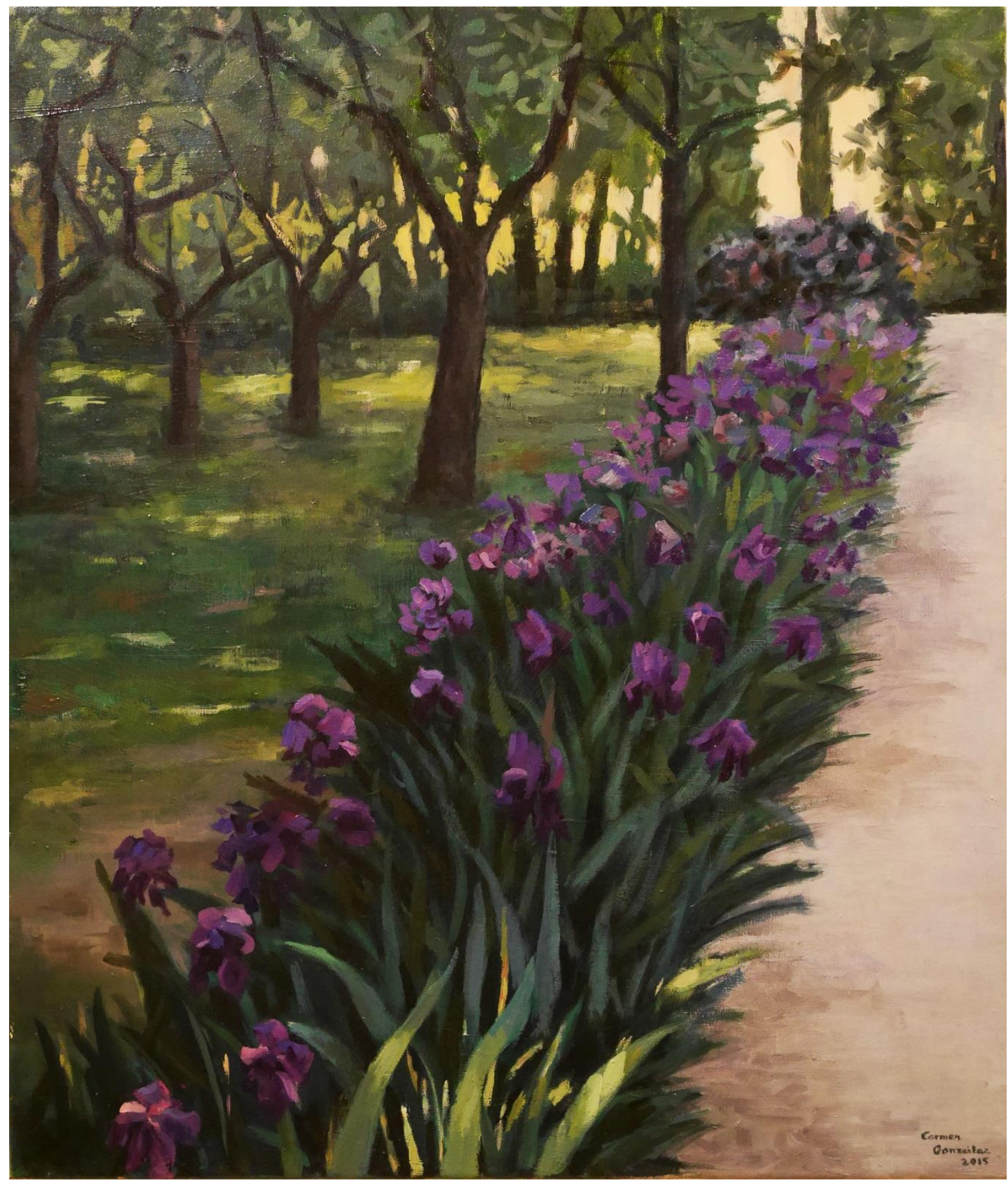


Madrid es una ciudad maravillosa para pasear. Sus plazas son acogedoras y sus calles están llenas de edificios con encanto, repletos de balcones de forja que parecen estar tejidos a mano, sin olvidar sus espléndidos y señoriales parques como "El Retiro", "Los jardines de Sabatini", "El parque del Capricho" etc. Entre ellos el parque llamado "La quinta de los Molinos" se caracteriza por sus numerosos almendros que cuando florecen, por su belleza, no tienen nada que envidiar al "Valle del Jerte". Completando dicha explosión de color encontramos numerosos caminos repletos de lirios que aumentan la belleza del parque. Son estos lirios los que inspiran mi cuadro.

Paseando por dicho parque se hace realidad la frase de Lope de Vega:

Madrid, que no hay ninguna villa, en cuanto el sol dora y el mar baña más agradable, hermosa y oportuna

(C) 2018 por los autores; Esta obra está sujeta a la licencia de Reconocimiento 4.0 Internacional de Creative Commons. Para ver una copia de esta licencia, visite http://creativecommons.org/licenses/by-nc-nd/4.0/. 